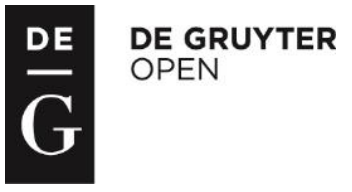

\title{
Adrian Poruciuc*
}

Faculty of Letters / Faculty of History Alexandru Ioan Cuza University of Iaşi, 11 Carol I Street, 700506 Iaşi, Romania e-mail: aporuciuc@yahoo.com

\section{Norbert Poruciuc**}

Faculty of Letters

Alexandru Ioan Cuza University of Iaşi, 11 Carol I Street, 700506 Iaşi, Romania e-mail: nporuciuc@yahoo.com

\section{AN ETYMOLOGICAL PROPOSITION: OLD GERMANIC G $\bar{O} D-S P \bar{O} D$ 'GOOD FORTUNE’ AS SOURCE OF OLD CHURCH SLAVONIC GOSPOD ' 'LORD, MASTER'}

\begin{abstract}
A thorough checking of the data provided by three etymological dictionaries, namely Georgiev et al. 1971 (s.v. gospod), Vasmer 1986 (s.v. gospod') and Derksen 2008 (s.v. *gospodb), would be enough to raise serious doubts about the application of the label "inherited" to *gospodb and its large Slavic family. Vasmer (1986, s.v. Russian gospod' 'the Lord, God'), states that the putative origin of the Russian word under discussion is a Proto-Slavic compound *gostbpodb; but it is also Vasmer who mentions that some outstanding linguists (including Antoine Meillet) objected to the mainstream etymological interpretation of gospod'. More recently, Derksen has stated that there is "no convincing explanation" for at least one element of the Proto-Slavic reconstruction *gospodb. By starting from such doubts and uncertainties, the authors of the present article will propound an etymology according to which *gospodb and its derivatives - to be found in Slavic languages as well as in Romanian actually reflect a very early borrowing of the Old Germanic compound which is still visible in English godspeed.
\end{abstract}

Keywords: mainstream etymologies, reconstructions, Old Slavic material, Old Germanic proofs, a new solution

\section{Frail reconstructions}

All relevant attestations indicate that the gospodb lexical family is quite widespread in Slavic. Among the Slavic cognates of Russian (Russ) gospod' and of its family (which includes gospoda, gospodar' and gospodin) Vasmer mentions the following: Bulgarian (Bulg) gospod, gospodar, gospodin; Serbian-Croatian ( $\mathrm{SCr}$ ) gospod, gospoda, gospodar, gospodin; Slovene (Sln) gospoda, gospodár, gospod; Old Czech $(\mathrm{OCz})$ hospod and Czech $(\mathrm{Cz})$ hospoda, hospodár Polish (OPol) gospodzin and Polish (Pol) gospodarz; Upper Sorbian (USorb) hospodaŕ and Lower Sorbian (LSorb) góspodar. ${ }^{1}$ The basic meanings of such Slavic terms go from 'dominant male figure

\footnotetext{
*Prof. Emeritus Adrian Poruciuc teaches linguistics to students of the Faculty of Letters and he is a supervisor of doctoral students of the Faculty of History at the Alexandru Ioan Cuza University of Iaşi. His main interests are in the Indo-European domain, in glottogenetics and in archaeomythology.

**Dr. Norbert Poruciuc is a lecturer at the English Department of the Alexandru Ioan Cuza University of Iaşi. He teaches history of English and translation methodology.

${ }^{1}$ See Vasmer 1986, s.v. gospod'.
} 
of a household' to 'master', 'ruler' and eventually to 'the Lord'. The number and spreading of those cognates seem to impose the idea that the lexical family under discussion comes from Proto-Slavic times. As regards early attestations, terms such as gospodb, gospodin gospodar, though) occur in Old Church Slavonic (OChSl) documents, as indicated in Georgiev et al. 1971 (s.v. gospod); in Russian such words were recorded in $14^{\text {th }}$ century documents (see Vasmer 1986, s.v. gospoda and gospod').

Also, the solid position of Bulgarian gospod is indicated not only by its basic meaning ('the Lord'), but also by the impressive number of Bulgarian derivatives to be found in Georgiev 1971 et al., s.v. gospod, where there are references to gospodar ('master, owner, ruler'), gospodarica, gospodarka, gospodaruva, gospoden, gospodin, plus names of plants such as gospod'ova momička, gospod'ovi hambari, etc. Etymologically, the same dictionary presents gospod as based on a ProtoSlavic (PSlav) compound, *gastbpadb. The latter is referred to (or, rather, is "etymologically inspired" by?) Latin hospes, hospitis 'master of guests', which, in its turn, is explained as based on Proto-Indo-European (PIE) *ghos-ti- 'stranger, guest, host' + *poti- 'powerful, lord'. Among the Indo-European roots given in the Appendix of AHDEL (1973) there is a *ghos-ti (=ghosti-s in Pokorny 1959, nr. 453), with the main meanings given as "stranger, guest, host." The root under discussion is presented as base of Indo-European words such as Old Norse gestr ("guest") and Latin hostis ("enemy (< stranger)"); the same entry of the Appendix also refers to a contracted compound with a double reconstruction, *ghos-pot- or *ghos-po(d)- ("master of guests"), which supposedly accounts for both Latin hospes ("stem hospit-") and "Common Slavic" *gospodì ("lord"), as base of Russ gospodin ("sir, master").

In Georgiev et al. 1971 (s.v. gospod) the second member of a PSlav compound reconstructed as *gastb-padb (not *gostb-podb, as propounded by Vasmer 1986, s.v. gospod') is presented as a cognate of Indo-European terms such as Lithuanian pats ('spouse'), Old Indic páti-, Avestan paitiand Greek -potess ('master, ruler') - all these with a well-preserved $t$. The same series includes the second member of the Gothic compounds brup-faps 'bridegroom' and hunda-faps 'centurion, chief of a hundred-men military unit'. In the same entry of the above-mentioned Bulgarian dictionary there follows a series of complicated (and hardly persuasive) arguments, all meant to justify the derivation * gastbpadb > gospod, and especially meant to explain the troublesome $d$ of the Slavic term. The latter should actually have a $t$, just like its putative cognate, Latin hospes, hospitis. ${ }^{2}$

Worth mentioning at this point is that Derksen (2008, s.v. *gospodb) - for all his indication of PIE * ghost $^{h}$ (i)-pot- as base of an inherited PSlav *gospodb (that is, neither *gastbpadb nor *gostbpodb), and for all his joining the mainstream assumption of a connection with Lat hospes - closes the entry under discussion by the following statement:

To my knowledge, there is no convincing explanation for the problem that the Proto-Slavic etymon [that is, *gospodb,] has a $* d$. According to Ernout-Meillet (529), the variation between *pot- and *pod- is old [...], but in view of Winter's law this explanation does not work for Slavic. $^{3}$

The troublesome $d$ is also observed by Buck (1988, 19.41 MASTER), who considers that OChS1 gospodb reflects "probably gos-pod $\check{~}$ from *gosti-pot (change of dental variously explained)." Our arguments, presented below, make the various explanations for the $d$ of OChSl gospodb appear as superfluous, since the voiced dental under discussion reflects a quite regular Germanic consonant, in

\footnotetext{
${ }^{2}$ However useful Latin hospes ('guest, stranger') may have been for the mainstream etymology of Slavic gospod, the Latin word is far from being clear as a contracted compound. Here is what Ernout and Meillet's dictionary (ed. 1985) gives under hospes, -itis (our translation): "The word has the sense originally expressed by hostis [...], and one may be tempted to believe that it is a compound whose first element would be hosti-; but the dropping of the $i$ is rather surprising. As for the second element, one can only hypothesize on it."

${ }^{3}$ Winter's law (with Kortland's additions to it) regards Balto-Slavic vowel lengthening in certain positions. A number of "worries" about Winter's law were expressed by Collinge (1985: 225-226), who drew the following general conclusion: "Despite some acceptance of the Winter-Kortland thesis [...], much more work on the precise mechanics is needed." Our etymology of gospodb really does not depend on the validity of Winter's law, so we will not insist on the mechanics of the latter.
} 
a word that was borrowed from Germanic into Slavic very early, most probably before the eighthcentury divergence of Proto-Slavic into historical Slavic languages.

\section{Germanic evidence}

One interesting aspect is that the gospod entry in Georgiev et al. 1971 dismisses an etymological proposition (whose?) according to which the $d$ of gospod would indicate a Gothic origin of the Slavic word. Gothic certainly is important for the present article, but not for the sake of the above-mentioned Go -faps (< PIE *poti-); much more significant for this discussion are the Gothic terms gōps 'good' and gōdei 'goodness' as well as spēps 'late'. The last one is a cognate of West Germanic terms such as Old Saxon (OSax) spōd 'success' and Old English (OEng) spēd 'speed, success, wealth'(see below). We must first focus on the Germanic cognates of English good and speed, since we assume that Slavic gospodb is a very early Old Germanic loan, whose perfect cognate in Modern English is the compound godspeed, with the original meaning of 'good fortune'.

That there was an archaic Indo-European association between the notion of "fortune" and the notion of "divinity" (as "dealer of fortune") is a well-known fact. In early Germanic, there also was an association between "fortune" and "health" or, rather, "wholesomeness". For instance, Old High German (OHGerm) heil 'luck, fortune' was subsequently recorded in Middle High German with meanings such as 'health, happy turn, healing, help' (cf. Pfeifer 1989, s.v. Heil). Such linguistic facts can be referred to historical evidence too. In that respect, an Austrian historian, Wolfram (1995), in commenting on the status of early Germanic kings, observes that fortune was expected to be held by and to radiate from Germanic chiefs and kings. ${ }^{4}$ For an illustrative example - in referring to the conflict between two famous Germanic leaders, Marbod and Arminius - the same historian makes the following observations (p. 38, our translation):

Marbod was quite fortunate. But, especially in archaic cultures, fortune [Glück] counts not as accident, but as merit, and as a good trait of a man who is capable of being a king. The better is the one who is more fortunate [...]. Arminius probably had long worked at that fortuneconfrontation [Glücksvergleich] with Marbod.

The quotation above refers to a period in which the Old Germanic society was undergoing important transformations due to its contact with the imperial Roman world. It was at that time that the archaic Germanic notion of "fortune", as well as the notion of "kingship", began to shift to new meanings and implications. It was, most probably, also during the period under discussion when the form of the early Germanic compound gōd-spōd ('good fortune') was contracted to *gospod on Germanic soil. ${ }^{5}$ Phonetically, a contracted form such as *gospod reflects exactly the same simplification of a consonantal cluster (-dsp- > -sp-) and the same shortening of an originally long vowel (in front of the cluster) as the ones that led, in more recent times, to the form of English gospel, from Old English gōdspel (gōd 'good' + spel 'news, tidings'). Also phonetically, by starting from a rather transparent Germanic *gospod, there would be no more need of divergent reconstructions, either at the PIE level (*ghos-pot- vs *ghos-po(d)-) or at the PSlav level (Georgiev's *gastbpadb vs Vasmer's *gostbpodb vs Derksen's * gospodb). ${ }^{6}$ More particularly, by assuming that PSlav * gospodb simply derives from

\footnotetext{
${ }^{4}$ Cf. Wolfram 1995: 21 (our translation): "When honor [Ehre] is intact, wholesomeness [Heil] beams out. [...] It is kings who hold the biggest portion of wholesomeness."

${ }^{5}$ We will apply the blanket formula "Old Germanic" to recorded and unrecorded varieties of tribal Germanic of the period between (approximately) the $2^{\text {nd }}$ century and the $6^{\text {th }}$ century of our time. Nevertheless, contacts between speakers of Proto-Slavic and speakers of Proto-Germanic can have occurred in even earlier times (see also below).

${ }^{6}$ Although, from a phonetic perspective, we focused mainly on the $t / d$ problem, at this point we will also refer to the vocalism of the above-mentioned reconstructions. It appears that the authors of the Bulgarian etymological dictionary Georgiev et al. 1971 wanted to suggest an early Proto-Slavic situation by the $a$-vocalism of their reconstruction *gastbpadb, whereas, for his * gospodb, Derksen took into account not only an already contracted form of an inherited compound, but also a later stage of the PSlav vocalism - see Carlton's table (1990: 98), which indicates a shift from PIE $\breve{o}$ to early PSlav $\breve{a}$ and then to late PSlav $o$. As we will point out in the present
} 
OGmc *gospod, the seemingly troublesome $d$ of the Slavic word appears as a quite regular continuator of a Germanic consonant, which was part of a Proto-Germanic stem *spōdi- (see below).

\section{Fortune as "divine allotment" in Germanic and Slavic}

We assume that in certain Slavic territories that came to be controlled by one or another Germanic tribal unit, approximately between the $3^{\text {rd }}$ century BC and the $2^{\text {nd }}$ century of our time, ${ }^{7}$ the Germanic loan *gospod eventually became a synonym of bog 'god' (cf. Russ bog, Ukr big, Bulg bog, Pol bóg, etc.). Also, certain derivatives of gospod began to be used as synonyms of the native derivative bogatb 'rich, fortunate' - cf. OChSl bogatb, Bulg bogat, Pol bogaty and Russ bogatyj, as well as Romanian (Rm) bogat 'rich' (as a Slavic loan). Etymologically and semantically speaking, a parallel presentation of the lexical families and semantic spheres of Slavic bog and of Old Germanic $s p \bar{o} d$, respectively, would be of help for this demonstration.

Slavic bog has clear Indo-Iranian cognates, such as Old Indic bhágas, used as an epithet of generous divinities, Sanskrit bhájati '(he) deals, distributes, apportions', Sanskrit bhaga 'good fortune', ${ }^{8}$ or Avestan bara 'god' (the last term being translated by Vasmer - 1987, s.v. bog - by both Russian gospod' and Russian bog). The above-mentioned Indo-Iranian terms, and their Slavic cognate, bog, ${ }^{9}$ can be referred to PIE *bhag- 'portion, share, to share, to get a share' (see that root in the AHDEL Appendix). It appears that there are no inherited Germanic terms based on PIE *bhag-. In exchange, Germanic preserved a number of terms based on another Proto-Indo-European root, namely *sp(h)eie-, which designated notions such as "fortune", "luck", "progress", "success" and "speed." In the German dictionary Pfeifer 2004, s.v. sputen 'to hurry' ('sich beeilen'), the following Germanic cognates are mentioned: MLGerm spōden ('eilig entsenden, antreiben'), OSax spōdian ('fördern'), MDu spoeden ('eilen'), OHGerm spuot ('Erfolg, Fortgang, Wesen'), OSax spōd ('Gelingen'), OSax spōdian ('fördern'), OEng spēdan ('Glück haben') and ModEng speed ('Erfolg, Eile'). According to Pfeifer, the enumerated terms reflect a Proto-Germanic stem *spōdi-, which appeared as a derivative ("mit Dentalsuffix") from a Proto-Germanic verb that survived in Old English as spōwan ('to succeed, to be successful') and in Old High German as spuoen, with similar meanings. In fact, the same dental suffix (as marker of a "ti-Abstraktum") occurs in several IndoEuropean cognates given in Pfeifer 2004, under sputen: OInd sphita ('reichlich'), Lat spatium ('Raum, Dauer, Länge'), as well as OChSl spěti ('fortschreiten, gedeihen, einen guten Fortgang haben') and Russ spet' ('reifen').

Old English is important for this discussion, since it contains the significant series of cognates that includes spōwan ('to succeed, to be successful') and spōwendlice ('thrivingly, prosperously, abundantly') as well as spēd ('speed, quickness, success, prosperous issue, means, substance, abundance, wealth, power, faculty, opportunity, means'), spēdan ('to speed, to have success, to succeed') and spédig ('having good speed, prosperous, having means, wealthy, opulent, rich, abundant, copious, powerful'), all extracted from Bosworth's dictionary (ed. 1983). The semantic-referential sphere of spēd is revealed by a particular Old English text, namely the "report" that a ninth-century Scandinavian navigator, Ohthere, delivered at the court of King Alfred the Great. About Ohthere, whose residence was somewhere on the Norwegian coast, we learn the following:

He was a very prosperous [spēdig] man, in properties that make up their fortune [spēd], that is, in wild deer $[. .$.$] .Those deer are called reindeer [. .$.$] . He was among the first men in that land;$

\footnotetext{
article, by assuming derivation from OGmc*gospod (from god-spōd) we implicitly obtain a perfect explanation for both the $d$ of PSlav * gospodb and for the $o$ vocalism of the latter.

${ }^{7}$ The very choice of such chronological limits indicates that we take into consideration the earliest stage of the Germanic expansion, that is, the one that took place before the spectacular expansion of the Goths. Archaeological evidence makes it clear that the earliest Germanic tribal units that moved southeast, to the area north and east of the Carpathians, belonged to the Elbe-Germanic group (see Elbgermanen as an entry in Hoops et al. 1989: 107-115). Such an aspect can very well account for the fact that the numerous gospod-loans in Slavic and Romanian correspond to archaic West Germanic terms, rather than to Gothic and Scandinavian ones.

${ }^{8}$ See terms given under bhag-1 ("to share out, apportion") in the AHDEL Appendix.

${ }^{9}$ In fact, the Slavic term under discussion was considered by several important scholars not as inherited, but as an Iranian loan in Slavic (as mentioned, with objections, by Vasmer, in his bog entry).
} 
but he had no more than twenty cattle, twenty sheep and twenty swine, and the little that he ploughed, he ploughed with horses. And their income mostly depends on the tribute that the Finns pay to them. The tribute is in deer hides, bird feathers, whale bone and ship-ropes, which are made of the skin of walrus and seal. ${ }^{10}$

Our Norwegian Viking appears to have represented the top position of a micro-tributal system imposed by Germanic intruders, as foreign elite in territories inhabited by non-Germanic natives. Ohthere presented himself as a prosperous man in terms of what belonged to his household proper, as well as in terms of what was brought to him as tribute.

Two important derivatives of the family of the Old English verb spōwan occur in the fragment above, namely spēd and spédig (see meanings above). In regard to the latter, Bosworth's dictionary of Old English also contains, as a separate entry, the compound gōd-spédig ('rich in good'), which is of particular interest for our etymological demonstration. On the one hand, OEng $g \bar{o} d$-spédig indicates that the traditional English well-wishing formula Godspeed has been wrongly interpreted in dictionaries; on the other hand, the respective formula etymologically clarifies Slavic gospod, as a loan from Germanic.

The etymological team of AHDEL (ed. 1973, s.v. Godspeed) as well as Hoad (The Concise Oxford Dictionary of English Etymology, 1986, s.v. god) presented the formula Godspeed as coming from the phrase God speed, interpreted as 'May God prosper (someone)'. Hoad compares Godspeed to good-bye. However, whereas good-bye appears to be a contraction of a formula such as "God be by you," the original (Old English) form of Godspeed must have contained gōd 'good', not god. Anyway, as regards Ohthere, he was not presented expressly as favored by any god, but simply as spédig, that is, as a man of good fortune. ${ }^{11}$

It is hard to decide whether in Ohthere's time (the ninth century) the archaic Indo-European idea of fortune as direct manifestation of divine benevolence still reflected a strong belief with Germanics. Nevertheless, such a belief must have been still strong in the traditional (pre-feudal) culture of the earliest Germanic tribal units whose traces were found by archaeologists in Slavic territories. ${ }^{12}$ It is such signs of Germanic presence among the early Slavs that accounts, in our opinion, for the success of a Germanic compound such as gōd-spōd 'good fortune', which probably entered Proto-Slavic already contracted as gospod.

\section{Conclusion}

With arguments such as the ones given above, we can first of all assume that Old Church Slavonic gospodb should not be regarded as an inherited term (from Proto-Slavic *gastbpadb or *gospodb, from Proto-Indo-European $*^{*}{ }^{h}$ ost $(i)$-pot-), but as based on a contracted form of Old Germanic gōd-spōd. The compound under discussion must have been borrowed by speakers of ProtoSlavic from temporarily dominant Germanics, in pre-feudal times, when the status of those intruders could grow no higher that the position of prosperous "franklins" of the Ohthere type. It was only when heirs of those well-to-do foreigners began to grow into proto-feudal lords that gospodb came to mean 'lord', and eventually 'the Lord'. We will add that the existence of a rich Romanian lexical family - which includes words such as gospod 'princely', gospodă 'noise', gospodarl 'well-off peasant', gospodar ' 'prince, ruler', gospodin 'lord, the Lord' and gospodină 'goodwife, housewife, lady of the house' - should also be taken into account in discussions such as the present one. "Comfortable" mainstream etymologies indicate that all those Romanian words are borrowings from Slavic. Nevertheless, at least some of them may prove to be based on Germanic borrowings into either substratal (pre-Roman) idioms or into early East Romance. But this is the subject of a more comprehensive article to-be.

\footnotetext{
${ }^{10}$ Our translation, after Whitelock 1990: 18-19.

${ }^{11}$ In that respect, let us observe what Bosworth (1983) gives as a second meaning of OEng spéd: "II. speed (as in good speed), success, prosperous issue."

${ }^{12}$ Kozak 1999 provides an archaeological view on the overlapping of pre-Gothic and Gothic types of Germanic settlements (mainly the ones representing the Przeworsk culture and the Černjakhov-Sântana de Mureş culture, respectively) north of the Carpathians, that is, precisely the area that several specialists have considered to be part of the Proto-Slavic homeland (see Birnbaum and Merrill 1985: 71-74).
} 


\section{Works Cited}

AHDEL. 1973. The American Heritage Dictionary of the English Language (ed. W. Morris), with an Appendix of "Indo-European Roots". New York: American Heritage Publishing Co.

Birnbaum, H. and Merrill, P. T. 1985. Recent Advances in the Reconstruction of Common Slavic (1971-1982). Columbus: Slavica Publishers.

Bosworth, J. 1983. An Anglo-Saxon Dictionary (ed. T. Northcote Toller). Oxford: Oxford University Press.

Carlton, T. R. 1990. Introduction to the Phonological History of the Slavic Languages. Columbus, Ohio: Slavica Publishers.

Coates, R. 2012. "to pare fulan flóde . óf pare fulan flode: on becoming a name in Easton and Winchester, Hampshire." In: Analysing Older English (28-34), eds. David Denison et al. Cambridge University Press.

Collinge, N. E. 1985. The Laws of Indo-European. Amsterdam/Philadelphia: John Benjamins.

Derksen, R. 2008. Etymological Dictionary of the Slavic Inherited Lexicon. Leiden/Boston: Brill.

Ernout, A. and Meillet, A. 1985. Dictionnaire étymologique de la langue latine. Paris: Klincksieck.

Gamillscheg, E. 1934-1935. Romania Germanica - Sprach- und Siedlungsgeschichte der Germanen auf dem Boden des alten Römerreiches, I-II. Berlin: de Gruyter.

Georgiev, V. et al. 1971. Bălgarski etimologičen rečnik (A-Z). Sofija: Akademija na Naukite.

Golden, P. B. 2011. Studies on the Peoples and Cultures of the Eurasian Steppes (ed. Cătălin Hriban). București: Editura Academiei Române.

Hoad, T. F. 1993. The Concise Dictionary of English Etymology. Oxford: Oxford University Press.

Hoops, J. et al. 1989. RLG - Reallexikon der Germanischen Altertumskunde, 7. Band. Berlin/ New York: Walter de Gruyter.

Kluge, F. 1995. Etymologisches Wörterbuch der deutschen Sprache (23 ${ }^{\text {rd }}$ edition, revised by Elmar Seebold). Berlin/ New York: Walter de Gruyter.

Köbler, G. 1989. Gotisches Wörterbuch. Leiden: Brill.

Kozak, D. N. 1999. “Așezările goţilor din Ucraina.” In: Interacademica, I-Les travaux de la V-ème session annuelle (47-58), eds. M. Petrescu-Dîmboviţa and S.D. Kryžyckij. Bucureşti: Institut Roumain de Thracologie.

Pfeifer, W. et al. 2004. Etymologisches Wörterbuch des Deutschen. München: Deutscher Taschenbuch Verlag.

Pokorny, J. 1959. Indogermanisches etymologisches Wörterbuch. Bern: Francke.

Poruciuc, A. 1999. "The Significance of Old Germanic Elements Preserved in Romanian.” In: Eurolinguistik - Ein Schritt in die Zukunft. Beiträge zum Symposion vom 24. Bis 27. März 1997 im Jagdschloß Glienicke (bei Berlin) (175-189), ed. Norbert Reiter. Wiesbaden: Harrassowitz.

Shevelov, G. 1964. A Prehistory of Slavic - The Historical Phonology of Common Slavic. Heidelberg: Carl Winter.

Vasmer, M. 1986-1987 Etimologičeskij slovar' russkogo jazyka, I-IV (ed. O. N. Trubačev). Moskva: Progress.

Whitelock, D. (ed). 1990. Sweet's Anglo-Saxon Reader. Oxford: Clarendon.

Wolfram, H. 1995. Die Germanen. München: Beck. 